University of Nebraska - Lincoln

DigitalCommons@University of Nebraska - Lincoln

Faculty Publications, UNL Libraries

Libraries at University of Nebraska-Lincoln

$1-1-1993$

Automating Idaho's Libraries

Mary K. Bolin

University of Nebraska--Lincoln, mbolin2@unl.edu

Follow this and additional works at: https://digitalcommons.unl.edu/libraryscience

Part of the Library and Information Science Commons

Bolin, Mary K., "Automating Idaho's Libraries" (1993). Faculty Publications, UNL Libraries. 44.

https://digitalcommons.unl.edu/libraryscience/44

This Article is brought to you for free and open access by the Libraries at University of Nebraska-Lincoln at DigitalCommons@University of Nebraska - Lincoln. It has been accepted for inclusion in Faculty Publications, UNL Libraries by an authorized administrator of DigitalCommons@University of Nebraska - Lincoln. 


\title{
Automating Idaho's Libraries
}

\author{
Mary K. Bolin
}

\begin{abstract}
The history of library automation in Idaho is illustrative of the course of library automation throughout the United States. Idaho's effort to automate its libraries is the story of cooperative ventures designed to help libraries work together to further their own interests. The role of LSCA, the Idaho State Library, the geography, and other unique characteristics of the state, as well as the role of WLN, are examined.
\end{abstract}

The history of library automation in Idaho is not so much the story of individual projects in the state as it is the story of the work that has been done to automate Idaho's libraries-cooperative ventures that have helped connect different libraries in the huge and sometimes isolated state of Idaho. Again and again, automation turns out to be something libraries are doing together, with the underlying goal, perhaps not of cooperation, but of fairly benign self-interest. A major part of the story of library automation in Idaho has been the story of work done by the Idaho State Library and of money from LSCA.

\section{HOW LONG IS THE HISTORY?}

When taking a historical perspective, the first question to ask is, how long is history? The history of library automation in Idaho, and

Mary K. Bolin is Head, Cataloging Department, University of Idaho Library, Moscow, ID 83843.

This is a revised version of a paper delivered at the Idaho Library Association Conference, Idaho Falls, ID, October 4-6, 1990.

Resource Sharing \& Information Networks, Vol. 9(1) 1993

(C) 1993 by The Haworth Press, Inc. All rights reserved. 
probably many other places, really goes back about a hundred years. Libraries as we conceive them, particularly public libraries, are a phenomenon of the late nineteenth century and a product of trends in education and social services then. Two things, besides the rise of public libraries, that date from the late nineteenth century and that are closely connected with the whole flowering of modern libraries and librarianship at that time are the development of modem office practices and the establishment of state libraries.

An ALA publication on the role of the state library tells us that "by $1890 \ldots$ public library services had become common and profuse enough for state government, or responsibility at the state level, to enter the cycle of continuing, improving and expanding such services to all citizens. Between 1890 and 1909 thirty-four states established an agency to promote public library activities." 1 States were given the authority to administer funds. This obviously gave them power and influence. State libraries have had the ability to influence the direction of library development. Examining how the funds have been administered shows what things state libraries consider desirable in library services.

At the end of the last century, at the same time as public library service was being expanded, the roots of what we now think of as library automation were already growing; and, while we may think of library automation as a phenomenon of the last twenty years or so, in fact automation is not new.

\section{To quote at some length from a recent text:}

Automation was at the heart of modern librarianship and the modern library movement. The extraordinary characters who founded that movement in the $1870 \mathrm{~s}$, particularly Melvil Dewey, promoted revolutionary concepts and new types of equipment to implement them. That is what we call automation today.

In addition to devising the Decimal Classification system, Dewey set up the first library school and participated in the founding of the American Library Association and Library Journal. [For some time he was also the state librarian of New York State.] All of Dewey's projects served to educate librarians to new concepts of librarianship-new notions about classi- fication and cataloging, in particular. For example, the notion of relative arrangement of books was utterly revolutionary. Previously, absolute arrangement where a book had a specific location-such as, Alcove 3, Shelf 5, Book 14-had been the rule. That meant that if the books were rearranged-for any reason-their catalog would be obsolete. Also, new books on a particular topic could not easily be placed next to other books on that topic. Decimal Classification, that allowed books to be shelved by their classification number, brought books on the same topic together and allows them to maintain their relative arrangement even if they are shifted or new books are interfiled. The Decimal Classification system was a monumental intellectual achievement and was one of the foundations of the revolution in librarianship.

The revolution in librarianship required new equipment as well. Dewey was a vigorous promoter of new equipment. $\mathrm{He}$ felt that founding the Library Bureau was one of his important achievements. He wrote, "I believe the Library Bureau to be the most important of the agencies (A. L. A., Journal, Bureau, and School) for advancing library interests ..." The Bureau manufactured and sold equipment and supplies needed by libraries. For example, the Library Bureau standardized the dimensions of catalog cards and sold the first modern card cata$\log$ cabinets. The card catalog allowed the notion of relative arrangement to be applied to the catalog. Previously, book catalogs-written or printed lists-had been common. A book catalog is easy to use and convenient, but is difficult to amend. Rather than attempt to amend their catalogs, libraries typically published periodic supplements. In order to search the catalog, the user would have to consult the basic catalog and all supplements.

We now take for granted, many other things in modern libraries which are based on relatively recent technological developments. Take the Reader's Guide, for example. The concept of a periodical index is simple. In the last century, a number of ambitious indexing projects were undertaken. Most failed because of the economics. There was a relatively small market and printing costs were high. As new material was 
indexed, cumulative editions were needed. However, resetting the type to produce cumulative editions was very expensive. In the $1890 \mathrm{~s}, \mathrm{H}$. W. Wilson solved the problem. He applied the notion of relative arrangement to printing. He realized that newly set linotype slugs could be interfiled with slugs set previously to create cumulative publications. He perfected this technique to produce the Cumulative Book Index and later used it to produce Reader's Guide and the other indexes of the H. W. Wilson Company.

Recently, computers have become available. They are letting us participate in a new revolution in librarianship. ${ }^{2}$

The concepts underlying library services, library practices, and library automation may be. simple, obvious, and desirable; but it takes technology to carry them out. Technology always seems a few jumps behind our own brains, too.

This leads one to ask why we talk about automation as a discrete topic, as if it were possible to separate it from library service in general. In the early eighties, PNLA Quarterly featured a speech by Ervin Gaines of the Cleveland Public Library. Among other things he said, "technology is not some clanking robot that will destroy our sense of values about books and education. ... The gadgetry is an extension of our arms and our brains to enable us to do more of the things that are at the heart of our profession to provide more books, readier access to them, and swifter and more precise service." 3 We're interested in making our operations and service better. We think automation has done or will do that.

The history of libraries, library service, librarianship, and library automation in the United States go back more than one hundred years. In its most narrow sense, however, the history of library automation in Idaho begins about twenty-five years ago. In the late sixties, people were trying to figure out the ideal future for Idaho's libraries. Several studies and long-range plans were written. ${ }^{4}$ The Library Services and Construction Act (LSCA) of 1964 was one reason for that planning. Long-range planning for library services in Idaho has been one of the most important things that the Idaho State Library has done as part of its administration of LSCA funds. Looking back at the planning that was done in the late sixties and early seventies and before, one can see without difficulty why libraries want to automate and why automation is such a good thing even if it is expensive and imperfect. In the late seventies, libraries were beginning to look forward to the end of card catalogs and other manual tools. Most news in the seventies (and before) was about new buildings. ${ }^{5}$ By the late seventies, that kind of expansion was over; and libraries were looking for other ways to extend service and pool resources. This led to things like participation in PNBC, the Pacific Northwest Bibliographic Center, ${ }^{6}$ a sort of proto-WLN, and other resource-sharing arrangements as well as union catalogs and serials union lists. ${ }^{7}$ These early efforts were service-enhancing but not labor-saving. That is, libraries wanted to do more but lacked the technology at that point to do it easily. The planning documents that were written fifteen to twenty years ago make it obvious that libraries and librarians in Idaho were looking for ways to share information and resources, to improve efficiency, to get access to the holdings of not just one library but all the libraries in the state and beyond, to do all the things libraries hope automation will do for them. Looking at the planning that was done twenty years ago points out what libraries may now take for granted. There is now a database of the holdings of many libraries in the state. In WLN's CD-ROM LaserCat, there is a cheap, portable version of this database. Many libraries have dial-up or other access to the holdings of libraries all over the U.S. We have CD-ROM and online access to many other databases. Interlibrary loan, cataloging, and reference services have experienced huge changes in the past twenty years because of the relative ease of access to all this information. The other theme that is hard to ignore in these planning documents from the 1970 s and earlier is that cooperation and resource-sharing has been the goal of nearly everything libraries set out to do, even if it is done with the ultimate goal of serving their own patrons better.

\section{$L S C A$}

In many ways the story of library automation in Idaho is the story of LSCA. ${ }^{8}$ This is particularly significant and relevant to Idaho because the predecessor of LSCA was the Library Services Act of 1956 that was created to extend library services to America's un- 
served rural populations. When LSA became LSCA, it was expanded to include a wide range of library services and to include urban as well as rural areas. The heart of LSCA, however, is the extension of library services to areas with inadequate libraries due to geographical isolation, sparse population, or lack of funds.

LSCA began with Title II0, whose goal was to extend library services to those inadequately served. It was limited to public libraries and had many broad objectives and uses including,

strengthening State library administrative agencies for meeting the needs of the people of the States . . establishing, expanding and operating programs and projects to provide: (a) State institutional library services; (b) library services to the physically handicapped; (c) library services for the disadvantaged in rural and urban areas; (d) library services to the elderly; increasing public library services or access to those services through effective use of technology; and strengthening metropolitan public libraries which serve as national or regional resource centers. 9

These things may not explicitly call for automation; but the concepts of resource and information-sharing and of extending service to all citizens are quite explicit; and it was obvious to librarians a computer would help accomplish most of those goals.

Title II of LSCA was restricted to the construction and remodeling of library buildings. The significance of Title II for libraries wishing to automate is that remodeling could be done for the purpose of "accommodating new technologies." Again it was limited to public libraries.

Title III of LSCA is for interlibrary cooperation and resourcesharing. The objectives are the "development of cooperative networks; and to establish, expand and operate local, regional and interstate networks or libraries which provide for the systematic and effective coordination of . . . resources." All types of libraries are eligible for these types of grants, and the funds may be used fairly freely for developing and operating cooperative systems and networks. The libraries of Idaho have gotten much good out of Title III, and we continue to do so.

\section{LSCA AND THE STATE LIBRARY}

The way the Idaho State Library administers LSCA funds is basically this: ". . . an ongoing planning process for the improvement of library services in Idaho ... began in 1986 with the State Library Strategy Study. The Study assessed the role of the State Library in meeting the needs of the library community for continuing education, consulting services and automation assistance ..." 10

Idaho's library needs were identified at the local level during the Strategy Study. These needs were primarily in the areas of continuing education, consulting services, and automation assistance. The State Library developed six broad program goals to meet these needs and then looked at the objectives of LSCA Titles I-III to develop priorities for funding projects based on those objectives, that are based on the six goals, that are based on our three needs! How does this translate into real benefits and real projects for real libraries? This can be illustrated by looking specifically at a couple of the six program goals and by examining the progress that has been made toward those goals. One of the six goals that is particularly relevant to automation is:

Improve the ability of libraries to access resources.

Some specific activities that were developed to help reach that goal are:

Continue to build upon current efforts to support library automation.

More specifically,

Continue to support public library RECON and addition of holdings to larger databases,

Improve access to resources statewide by linking existing systems and/or combining existing records into a central database and/or supplementing electronic access with offline, print or fiche access. 
Some practical results of just this one goal and these few activities are:

- 48 public libraries each have a microcomputer, printer and modem

- 22 libraries have undertaken retrospective conversion projects

- 12 will have their records added to WLN

- 90 public libraries each received a copy of the WLN Resource Directory for use in cataloging and interlibrary loan

- 33 public libraries have the WLN LaserCat (CD-ROM database), card printing program and required equipment. ${ }^{10}$

\section{$W L N$}

Although libraries have always formed relationships and alliances based on geography, size, collections, politics, expediency, altruism, and so forth, the 1970s saw the development of several automated networks that allowed libraries to share cataloging information. As with many things, libraries did not know the true significance of these networks until after they had been going for quite a while. Many librarians saw these databases as a way to do something about the backlogs that were growing because of the large acquisitions budgets of the 1960s and the information explosion that began around the time of World War II. Many libraries who joined networks in the early and mid-seventies especially saw them not just as a way to get cataloging information but as a way to get catalog cards. It was not until well into the 1980 s that many people realized what computerized bibliographic information is really good for, and by that time some people had made decisions they regretted. Idaho's libraries have been able to avoid that short-sightedness to some extent. The independence and individualism of the American West and its inhabitants are well-known as are the geographical and self-imposed separation and isolation of the Northwest, along with what may be called "ecotopianism" after the science fiction novels by Ernest Callenbach ${ }^{11}$ that are set in the Northwest. These are the elements that have contributed to the development of WLN. There are several striking characteristics to the network that may also be characteristic of the Northwestem United States. The first is WLN's regional character. It is the only major network that has stayed geographical in nature, at least up to this point. Another characteristic of WLN, that is partly an outgrowth of its regional character, is the cooperativeness between member libraries and between members and WLN staff. This spirit has obviously led to a number of the cooperative automation ventures that have developed. A third characteristic of WLN, that also has some connection with the first two, is a sort of obsession that WLN members have with the cleanness and purity of its database, that some might see as a kind of psychological equivalent of the protectiveness that residents of the Northwest feel toward the region. A final characteristic of both WLN and WLN members is a combination of conservatism with a very progressive approach. Libraries generally waited longer to join WLN than their counterparts in other areas took in joining OCLC. WLN itself has been very cautious about implementing new things and very prescriptive about what may go into the database. On the other hand, OCLC in particular, at least in the $1970 \mathrm{~s}$, was very much oriented toward card production rather than the creation of a machine-readable database.

\section{WLN'S HISTORY}

WLN began as the Washington Library Network. ${ }^{12}$ In the late 1960 s, the Washington State Library began work on a statewide resourcesharing network. Once more, this shows the power and the interests of state libraries as well as the thinking going on then because of LSCA, particularly Title III-resource-sharing. In 1972, the first WLN Resource Directory was produced in book form from the holdings of 10 libraries in Washington. The system that produced this printed Resource Directory operated in batch mode. The Boeing Company computer services programmed the online version of the WLN system in 1975. The next year, the Washington State legislature recognized WLN as a state agency; and, in 1977, the online cataloging system began operating with 10 member libraries. In the next few years, libraries in Washington, Idaho, Alaska, Oregon, Montana, and British Columbia joined WLN. There were 100 members in the early 80 s with that number growing to 360 by 1988 . There are 10 Idaho libraries who are contributing members of WLN. This figure includes both contributing members and search-only. The Washington Library Network became the Western Library Network in 1985 and in 1990 gained private, non-profit status to become simply "WLN." 


\section{CHARACTERISTICS OF WLN}

WLN's database now includes more than 7,000,000 records, not only records contributed by WLN members, but those from national libraries such as the Library of Congress, the National Library of Canada, the U.S. Government Printing Office, and the National Library of Medicine. ${ }^{13}$ There are also tape-loaded records from the University of Washington, one of the largest OCLC libraries, as well as cataloging records from some of the largest contributors to the RLIN database. In this way, WLN has preserved its regional character while broadening its scope in recent years to enhance and enlarge the database with records from elsewhere. It is ironic that the excellence of the WLN software has, in a sense, been an impediment to local automation in libraries in Idaho and other Northwestern states. More than the other major networks, WLN has the characteristics of a local system as well as a bibliographic utility. Two things in particular make this true. The first is the powerful searching capabilities of WLN. The ability to do title keyword searching and subject searching, in particular, give WLN some qualities of an online catalog rather than merely a resource database for cataloging. Second, and equally important, the holdings file and the bibliographic file are separate. This means that each library that has attached its holdings to a bibliographic record can see what local call number it has used and what special locations, if any, the book is located in. This can be interpreted in two ways: that having WLN has given libraries the leisure to wait for the "perfect" system rather than compromising by selecting what is currently available at anytime, or having WLN has caused libraries in Idaho and the rest of the Northwest to lag behind in the race for the state-of-the-art system. One thing is certainly true. The local system capabilities of WLN have made its members demanding consumers when shopping for a system.

\section{RETROSPECTIVE CONVERSION}

The first step toward automating is to convert manual records to machine-readable form. In some ways, retrospective conversion was the automation activity of the late seventies and the eighties.
More than anything else, Idaho's libraries, like those of all the other states, were building their databases for a variety of reasons-to get rid of card catalogs, to facilitate reference and interlibrary loan, to accomplish all those things we think automation is good for. The two largest Idaho contributors to the WLN database are the University of Idaho and Boise State University. The growth in their WLN holdings illustrates the impact of the network. In June 1979, the University of Idaho had 1,464 holdings in WLN; two months later there were 7,596; one year later, in September 1980, 20,864; in March of 1992, nearly thirteen years later, 424,242. Boise State University had 8,615 in June of $1979 ; 17,070$ two months later; 28,332 the next year and 287,174 in March 1992. ${ }^{14}$ Idaho's libraries may sometimes feel a little behind the times, a little slow. But there are many very large libraries elsewhere in the country, who may have an integrated, automated library system and yet are still struggling to get their manual cataloging records completely converted.

This leads to reflection on whether it is easier or harder for libraries in Idaho to automate than it has been elsewhere. The answer is perhaps "both." One reason for this is the size of libraries found in Idaho that goes from tiny to moderately large. If a library is very small, there may not be money to automate; and there may not be an urgent reason because smaller manual systems can work quite well. A medium to moderately-large library may be able to get along without automation though it would be desirable. Very large libraries were sometimes "forced" to automate in the early seventies because their manual systems were falling under their own weight. Maintaining even a small card catalog is a burden. Maintaining one the size of a football field is an impossibility. Therefore, libraries in Idaho have had the leisure to wait until systems got cheaper, more powerful, and easier to install and use.

\section{LOCAL SYSTEMS IN PLACE}

There are a growing number of automated systems installed around the state. ${ }^{15}$ A few examples follow: an integrated online library system has been in place at Idaho State University in Pocatello for more than five years, and North Idaho College in Coeur d'Alene and Ricks College in Rexburg each have locally-developed online systems. There are also a number of public libraries that have 
some of their functions automated. The Moscow-Latah County Public Library uses Follett's PC-based Circt as an online catalog and circulation system, for example. A number of school libraries around the state have automated systems, either off-the-shelf packages or locally-developed applications.

\section{MULTIPLE LIBRARY SYSTEMS}

Even more significant than the local systems in place around the state are the efforts to link more than one library. One of these is Valnet, an automated library network in the Lewiston area. Its members include libraries of several different types-academic, public, and school. Another multi-library system is the Eastem Idaho System, in which three public libraries in Eastern Idaho are sharing a Dynix automated system. Still another is the Boise-based CLSI group, four public libraries in the Boise area who share a circulation system. Another example is the Cooperative Information Network that links six libraries in Northern Idaho. Boise State University and the Idaho State Library have a shared GEAC Advance system online. The University of Idaho has recently joined with Gonzaga University and Whitworth College in Spokane, Washington to form the INLAN consortium, that uses the CARL system.

\section{SPECIAL LIRRARIES}

Idaho also has a number of special libraries. ${ }^{16}$ Among special libraries in Idaho, medical libraries in particular have been forwardlooking. In the mid-seventies, they formed the Idaho Health Libraries Network, partly with a grant from the National Library of Medicine. This network was formed for resource-sharing and to provide access to the Medline database for those in the state who had not had it. It is easy to see the particularly Idahoan philosophy behind this, to pool scarce resources and find strength in numbers. A 1979 article in The Idaho Librarian remarked:

Idaho has some severe deficiencies in the health information arena. It has only 52 hospitals, and of these only ten have libraries that are active on a day-to-day basis. Idaho also has no medical school, and thus no nationally recognized medical resource library. However, eight developing hospital libraries make the picture look brighter. In addition, Idaho State University with its Colleges of Medical Arts and Pharmacy, has more than 6,500 medically-related volumes and over 650 medical journals. . . . Boise State University's nursing and respiratory therapy collections serve the Boise area well. ...17

The article goes on to emphasize the importance to the network of the Health Information Retrieval Network at St. Luke's Hospital in Boise that had access to Medline. The Medline searching was subsidized by a grant from the Idaho State Library, which again shows its interest in automation and resource-sharing. Ten years later, Idaho's medical libraries are continuing to cooperate with each other through consortia that provide access to Medline as well as to a union list of health science serials.

\section{$\boldsymbol{R L I N}$}

WLN is not the only utility in use in the state. ${ }^{18}$ Idaho State University is a member of RLIN and illustrates the way libraries form relationships. Libraries in North Idaho tend to look west to Washington State when forming alliances with other libraries. In South and Southeastern Idaho, libraries may look south to Utah. There are cultural and social reasons for this, but the geography of Idaho alone makes it not surprising. State lines don't always mean as much as other things, and even geography can sometimes be annihilated by technology. The WLN records of the six largest contributors to WLN are being loaded into RLIN. The University of Idaho, and perhaps others in the state, have dial-up access to RLIN to find records not found in WLN. We are less and less isolated, and different systems are beginning to talk to each other.

\section{IDAHO TELEFAX NETWORK}

One recent project has all the characteristics of all the efforts to automate Idaho's libraries. ${ }^{19}$ It takes advantage of new technology; it is for the purpose of resource-sharing; and it was done with LSCA 
money. That is the Idaho telefax network. This project is the fruition of a lot of plans that have been around for twenty years or moretechnology finally caught up. This LSCA Title III grant project lasted from April 1988 until August 1989 with seven libraries participating: The University of Idaho Library, University of Idaho Law Library, Idaho State University Library, Boise State University Library, Idaho State Library, Lewis Clark State College Library, and East Bonner County Library. The telefax network libraries sent and received ILL requests using fax machines. Participants kept statistics on type of material, type of patron, success rate, etc. The project was considered quite successful by its participants and has opened the door for more widespread use of fax technology for interlibrary loans, both for the transmission of requests and of the material itself.

\section{LASERCAT}

One of the most significant developments of all in the history of automating Idaho's libraries is the development in 1987 of WLN's CD-ROM catalog LaserCat. ${ }^{20}$ The unique characteristics of WLN that have made it so useful for regional cooperation-the regional membership, the powerful software, the separation of holdings information from bibliographic information, and the relative smallness of the database when compared to larger networks-made LaserCat possible. LaserCat is the CD-ROM version of WLN's database. It is inexpensive compared with online systems; extremely powerful compared with a card or microfiche catalog as well as with many supposedly more sophisticated online systems. It contains the cataloging records of more and more Idaho libraries, and more and more Idaho libraries have LaserCats. LaserCat represents the coming together of several things-the desire for a statewide or regional union catalog that was never satisfactorily realized, but is nearly so in LaserCat; the overarching goal of resource-sharing and extending service that is the basis of LSCA, of the Idaho State Library's work, and of the needs and desires of individual libraries; and the emergence of a technology that allows us to realize our goals cheaply and workably. Sixty-two Idaho libraries now have LaserCats for a total of 98 subscriptions in Idaho. WLN has devel- oped several new methods for libraries to add their holdings to the database using LaserCat, and this means that smaller libraries now have the means to contribute to WLN, whereas the cost may have been too high in the past.

\section{THE FUTURE}

The future is obviously going to lead us across state lines just as the past did. It doesn't take an oracle to see that the future holds more consortia, networking, and access to more and more different and remote databases, either on CD-ROM or online. We can see the waves that have washed across us during the history we've been talking about: first individuals and individual libraries, then state interest in library service, then attempts at cooperation and resource sharing, then automated networks, then local systems, then small networks, then access to the whole universe through networks like the Internet.

\section{CONCLUSION}

Libraries may hope for a single solution to library automation that fits neatly into one black box, while in fact solutions keep proliferating and are always messy. That is the nature of information and the nature of the world of information today. This has been a glimpse at the past; no doubt the future will be even more interesting.

\section{NOTES}

1. State Library Policy. Chicago: American Library Association, 1971. p. 1. 2. Bolin, Robert. Computer Applications in Libraries. Moscow, Idaho: Correspondence Study in Idaho, 1990.

3. Gaines, Ervin J., "Poets are not Peasants," PNLA Quarterly. 46, no. 1:6 (Fall 1981)

4. See issues of the Idaho Librarian and PNLA Quarterly during the mid-and late seventies for accounts of this planning.

5. See news columns in the Idaho Librarian and PNLA Quarterly during the early and middle seventies for news about building projects.

6. For a description of PNBC see: "Report to PNLA from the Joint Planning Team," PNLA Quarterly, 46, no. 4:2-4 (Summer 1982). 
7. Some of these efforts are described in Downing, Joan K. "ISU and the MULS," Idaho Librarian, 31, no. 3:100-102, (July 1979); and Baird, Lynn N., "Idaho Union List of Serials: Old Dream, New Tool," PNLA Quarterly, 53, no. 3:18-20 (Spring 1989).

8. LSCA Programs: An Action Report. Washington, D.C.: Office of Educational Research and Improvement, 1988 and LSCA Programs: An Action Report $\mathrm{II}$. Washington, D.C.: Office of Educational Research and Improvement, 1989.

9. Quoted material from 1991 Catalog of Federal Domestic Assistance, Washington, D.C.: Office of Management and Budget, 1991. pp. 766-768.

10. Idaho State Library. Idaho State Library Long-Range Plan for Implementation of LSCA Priorities, 1989-1991. Boise: Idaho State Library, 1988.

11. Callenbach, Ernest. Ecotopia: The Notebooks and Reports of William Weston, Berkeley, CA: Banyan Tree, 1975, and Ecotopia Emerging, Berkeley, CA: Banyan Tree, 1981.

12. For description and history of WLN see: "WLN Update" in issues of the Idaho Librarian from the mid- and late seventies as well as Aoyama, Karen M., "Idaho + WLN = Belter Library Service," Idaho Librarian, 31, no. 2:56-59 (Apr. 1979); and Baird, Lynn, "WLN and Idaho: A Successful Partnership," Idaho Librarian, 34, no. 1:16-18 (Jan. 1982).

13. Current information about WLN can be found in issues of the WLN Participant and WLNews Bulletin.

14. Statistics from WLN "Monthly Activity Reports."

15. See Watson-Boone, Peter, "Status Report on the Automation of Library Catalogs in the Idaho Public College and University Libraries," Idaho Librarian, 41, no. 3:68-69 (July 1989) as well as news columns in the ldaho Librarian and PNLA Quarterly during the mid-and late 1980 s.

16. For information about Idaho's medical libraries see Bierman, Sandy, "Idaho Hospital Libraries and Their Information Network," Idaho Librarian, 41, no. 3:56-57 (July 1989) and Schardt, Connie, "Hospital Libraries-the Quiet Idaho Network," PNLA Quarterly, 51, no. 3:53-54 (Spring 1987).

17. Squire, Jeannette Timmie. "Idaho Health Libraries Network," Idaho Librarian, 31, no. 2:65-67 (Apr. 1979).

18. Hayden, Maxine. "Automating Acquisitions at ISU," Idaho Librarian, 33, no. 2:54-57 (April 1981) and Watson-Boone, Peter, "Status Report on the Automation of Library Catalogs in the Idaho Public College and University Libraries."

19. Hook, Robert D. "Idaho Telefax Network Grant: Fina! Report." October 1989.

20. For information about LaserCat, see WLN Participant as well as Eckwright, Gail Z. "Launching LaserCat," PNLA Quarterly, 53, no. 4:23-25 (Summer 1989); and Eckwright, Gail Z. and Mary K. Bolin, "No Card Cat-No Problem! WLN's LaserCat Provides Another Opportunity for Cooperation," $R Q, 29$, no. 4:525-533 (Summer 1990). 